\title{
Innovation in Maritime Logistics Industry of Bangladesh for Doing Port Transport Business
}

\author{
Razon Chandra SAHA \\ Center for Higher Studies and Research, Bangladesh University of Professionals, Mirpur Cantonment, Dhaka 1216, Bangladesh
}

\begin{abstract}
Bangladesh has the lucrative maritime load centers or seaports to provide maritime logistics support as well as to do port transport business regionally with India, Nepal and Bhutan and internationally with China and Myanmar. Existing land ports as alternatives of dry ports are main strength of Bangladesh to connect with the seaports and offer port transport business for earning foreign exchange and able to play a vital role to develop the South Asia, SW part of China and Myanmar by serving the maritime logistics facilities timely and economically. In here, dry port concept is the main theme for developing port transport business where road, rail and waterways are the connectors or modes of transportation and seaports are the linking points with the sea world. Innovation is the key of success of a business idea and plan where maritime logistics business is the new opportunity of Bangladesh by using natural resources or seaport by mounting infrastructure facilities of nodes (seaport and dry port) and modes (road, rail and waterways) and adding speedy port transport for all. The intermodal freight transportation system is the new concept for creating the new era in the port transport business by using nodes, modes and technology innovatively. This research aims to find out the possible ways and innovations in maritime logistics for doing port transport business by using seaports and land ports by applying qualitative research methodology. The paper also describes the innovations of Rotterdam port as case study that facilitated the needs of a hinterland in Europe to explore the innovations for Bangladesh maritime logistics industry.
\end{abstract}

Key words: Innovation, maritime, business, infrastructure, intermodal, rotterdam, hinterland.

\section{Introduction}

Innovation is the way of adapting in the new environment at the stage of demand that derived naturally or concentration of human being to cope with the age and trends of globalization [1]. To unfold, seaports are the center of maritime logistics and the hub of world trade where spokes are the manufacturing sites or consumer's city or living place. From the very beginning of world merchandize trade, seaports are playing vital role in the national economy by serving or driving import-export trade. But nowadays, it is not for domestic's purpose only, it's a source of foreign exchange by doing port transport services to others. Traditional port transport business is not in a stage to sustain in this competitive world. Foreign direct investment or domestic's industrial promotion or

Corresponding author: Razon Chandra SAHA, Ph.D., researcher, research fields: transport, logistics and supply chain. attraction to the buyers and sellers of the world's highly depends on the maritime access for quick transfer of cargo that is the headachy shipper/consignee/trader. Due to geographical and geopolitical advantages of Bangladeshi seaports in the Bay of Bengal comparing with Kolkata (India) and Sittwe (Myanmar), port transport business is waiting for Bangladesh to take the coverage of hinterland opportunity (West Bengal and Seven Sister of India, SW part of China, Nepal and Bhutan and Southern part of Myanmar). In this connection, seaport and infrastructure development are essential to take the opportunity and strengthen the maritime logistics industry of Bangladesh.

Driven in particular, Bangladesh has the lucrative maritime load centers or seaports to provide maritime logistics support as well as to do port transport business regionally with India, Nepal and Bhutan and internationally with China and Myanmar. Existing land ports as alternatives of dry ports are main strength of Bangladesh to connect with the seaports and offer port 
transport business for earning foreign exchange and be able to play a vital role to develop the South Asia, SW part of China and Myanmar by serving the maritime logistics facilities timely and economically. In here, dry port concept is the main theme for developing port transport business where road, rail and waterways are the connectors or modes of transportation and seaports are the linking points with the sea world. Innovation is the key of success of a business idea and plan where maritime logistics business is the new opportunity of Bangladesh by using natural resources or seaport by mounting infrastructure facilities of nodes (seaport and dry port) and modes (road, rail and waterways) and adding speedy port transport for all. The intermodal freight transportation system is the new concept for creating the new era in the port transport business by using nodes, modes and technology innovatively.

Having in mind, the concept of logistics innovation that focused on the inter-organizational connections between seaport and port actors within the given service supply chain [2]. Mention that innovation is the most important driver of organization's competitiveness in the advanced world economics where seaports are big investment for a country and region in the welfare of the people humanitarianly. This research started with the vision of searching some innovations of maritime logistics that are related to the existing port transport scenario of Bangladesh also linked with business opportunity or selling port services to the neighbors and others regionally and internationally. In here, three fold research methodology is applied to get the possible innovations for the maritime logistics industry. Firstly, content analysis from the secondary sources and bought one case study that focused on Port of Rotterdam for benchmarking with Bangladeshi ports. In here, innovations of Rotterdam port tested and directed to the Bangladeshi port to add in their port services sales and marketing. Lastly, qualitative research methodology is applied and telephonic interview of experts were conducted directly in the maritime sector and with others related to this research. Taken as a whole, literature review, case study and qualitative research findings are discussed, compared and contrasted to get the innovations that may apply to the Bangladesh maritime logistics industry for starting port transport business and added future directions in last section.

\section{Innovations in Maritime Logistics}

Innovation is the implementation of new ideas but it is a complex process because of its involvement with many factors and processes like institutes, customers, authorities, financial organizations and institutions including many wings of the government who drives the innovative work from the frontline to achieve the sustainable goals of the industry [1,3].To cater the maritime business as well as increase the hinterland and foreland, innovations are appreciated to render attractive business packages in the folder of port service marketing to withstand within the domestics, regional and international ports to get the customer and retain them pleasantly. The first innovation of the maritime logistics is to offer easy access to the port user and increase the number of port users irrespective of domestics and others that means to increase the hinterland from the port protected area. Research found some innovations that may apply to the Bangladeshi seaports to offer port transport business, optimistically.

In addition, intermodal freight transport promotion is necessary to reduce the transport cost and avoid the multiple cargo handling at port and other places in an given supply chain. In this position, Hanssen et al. [4] argued for generalized transport cost in intermodal freight transport to make it popular as ever-growing freight transport volumes and increasingly congested roads that remarked on the agenda of public and private players in the maritime logistics and transport industry. Connectively, the growth of intraregional trade and the expected growth of containerized transport in Asia that are demonstrating the need of intermodal freight transportation inevitable [5]. For the development of 
intermodal freight transportation, it requires the considerations of three attributes which are as follows:

Transport links or modes: In order to promote the Intermodal freight transportation, it is essential to improve the links of road and highways, railway networks and inland waterways.

Transport nodes: It is highly required to develop the seaport, dry port, inland terminals to perform at seaport or good inland distributions.

Provision of efficient services: Arrangement of good logistics and supply chain ensures the maritime logistics and port transport to serve the users timely and economically.

Development and changes in port hinterland are major concern of world trader and paying considerable attention as they present substantial opportunities to improve the efficiency of global freight distribution in the aim of promoting shipping business by increasing hinterland [6]. And innovation in technology and electronic data management in the maritime logistics industry of Bangladesh. In this context, Acciaro [7] concerned for environmental sustainability of seaports and its logistics chain where port authority, policy makers, port users and local communities are growing their opinion to reduce the emissions from the vessel, truck and trailers and searching the way of less emissions of $\mathrm{CO}_{2}$ to protect the world inexorably. In here, technological and organizational innovation may help to reduce the tension of stakeholders and others. In the way, Rodrigue and Notteboom [6] found the strong interdependency between a port's foreland and hinterland because of containerization and designing of intermodal freight transportation. Therefore, foreland connections are innovation to promote maritime logistics industry. The necessity of sustainable port management and connecting with the supply chain network through integrated logistics management and infrastructure development with the consideration of environmental management of all innovations. In relation to that port expansion is the product of evolving maritime technologies and improvements of cargo handling at seaport initially, however, nowadays, it is going out of port protected area like Chittagong Port built Inland Container Depot-ICD in Dhaka and assisting government in building Riverine Inland Container Terminal-RICT in Pangaon and new port in Payra, Patuakhali that will play a role to serve the West Bengal, India, moreover, developing deep seaport in Bangladesh to mitigate the demand of the region dynamically [8].

\section{Port Transport Scenario in Bangladesh}

Currently, there are three seaports in Bangladesh in the operations of handling cargo and container and one riverine container port specialized in container. Most of the cargo and containers are performing for Bangladesh only with the limited edition of serving India, Nepal and Bhutan regionally. Details of the seaports and other port transport facilities are as below.

\subsection{Chittagong Port}

The Chittagong Port, under the management of Chittagong Port Authority-CPA is the principal seaport of Bangladesh who handles approx. 92\% of seaborne trade of the country and mounts the great importance in the national economy [9]. The port has good reputation among the Asian seaports with a good standing in the port world. Remarkably, Chittagong port is the economic gateway of south Asia in providing necessary services and facilities to the port users efficiently and effectively at competitive price.

Hamburg Port Consultancy-HPC drafted and forecasted on Chittagong Port Master Plan that projected the container traffic to $2.7,4.4,5.1$ and 5.4 million TEUs for the year 2020, 2025, 2030 and 2040 respectively [11]. However, a total of $30 \%$ of the container traffic originates/is estimated in the Chittagong region. Therefore, Dhaka's expectation to and from container traffic may be $1.89,3.08,3.57$ and 3.78 in million TEUs in the year 2020, 2025, 2030 and 2040 respectively as per HPC report. 
Journal of Shipping and Ocean Engineering 7 (2017) 78-92

doi 10.17265/2159-5879/2017.02.005

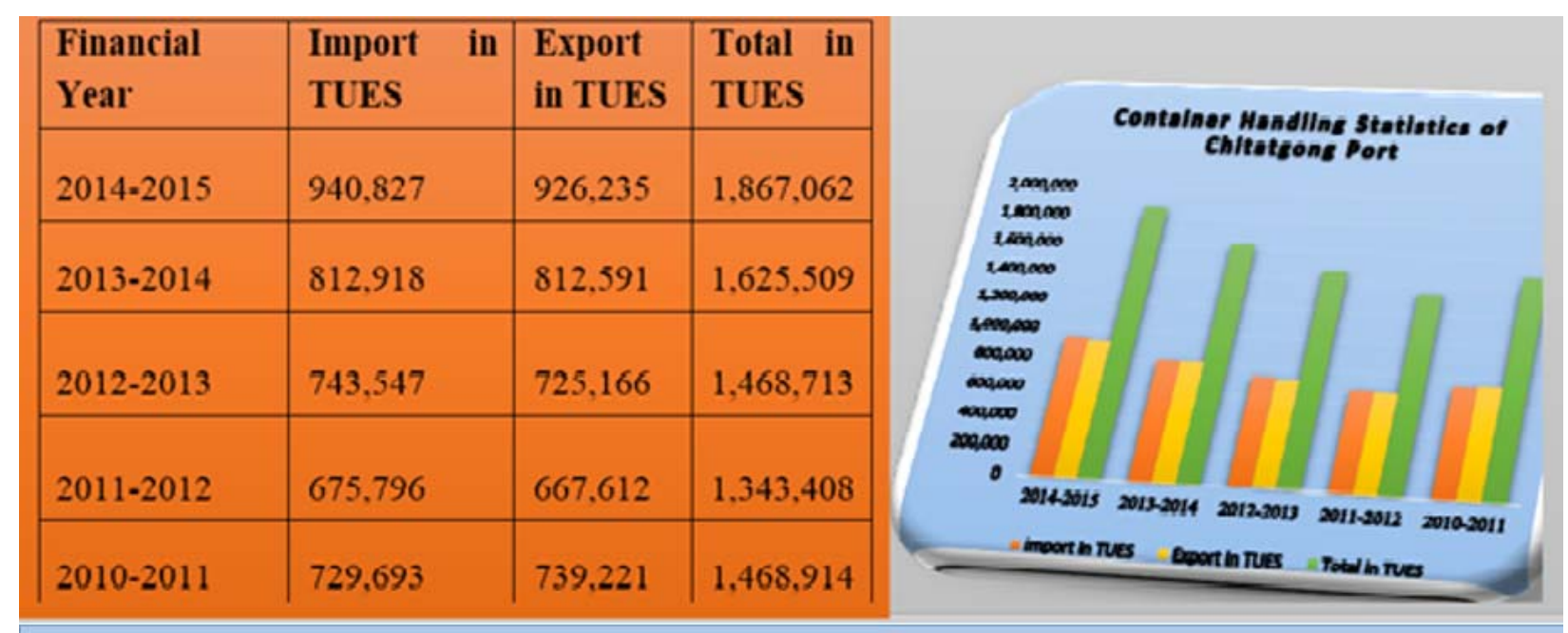

Fig. 1 (Table and Chart). Performance of Chittagong Port 2011-2014 [10].

\subsection{Mongla Port}

Mongla Port is one of the seaports of Bangladesh that is eco-friendly and well protected by the mangrove forest Sundarbans. Having the capacity of handling 6.5 million Metric Ton cargo and 50,000 TEUs container per year, unfortunately, it is underutilized [12]. Due to lack of fair road communication and bridge connections, business communities are not interested to use the port. Hopefully, after the completion of PadmaBridge, Mongla seaport will serve as like Chittagong port also to the neighbors as per capacity and easy connections to India by Rail and Road.

\subsection{Payra Seaport}

This is the newly established seaport of Bangladesh inaugurated in 2016. Payra seaport is the 3rd sea port of Bangladesh located in general area on the bank of Rabnabad Channel under Kalapara, a sub district of Patuakhali [13]. In order to increase the economic activities in the central zone and meet the future demand, Payra Sea Port was established by the government and inaugurated in 2016. Government has taken Short, Mid and Long Term Plan to develop a state of art modern sea port.

\subsection{Pangaon Container Terminal}

BIWTA (Bangladesh Inland Water Transport
Authority) and the CPA (Chittagong Port Authority) jointly built first RICT in Bangladesh named Pangaon Inland Container Terminal-PICT that expected to play a positive role in the country's economic development by opening up a new horizon in the transportation of exported and imported goods through waterways [14]. Pangaon container terminal-PICT was built by the fund of CPA and its operation was privatized in the aim of easy movement of cargo and container from Chittagong to nearby Dhaka [15]. This initiative also planned to reduce the pressure of transporting cargo by truck and container in Dhaka-Chittagong highway and representing Chittagong port near the capital city Dhaka for assisting shipper consignee to catch the shipment schedule timely. Although, PICT has modern infrastructure and international standard equipment's, it failed to attract users due to lack of proper marketing strategies and the absence of innovative shipping services.

\subsection{Other Port Facilities}

Chittagong Custom House listed 14 off-docks in Chittagong for import export activities, in addition, managing Dhaka ICD (Inland Container Depot), shipper premises of all over the country also specialized cargo at anywhere in the quota of others [16]. In fact, Chittagong port does not handle any export stuffing of container where off-docks are doing 
excellent maritime logistics support to the port.

Overall, port facilities are not adequate or up to the mark in terms of managing domestic's trade and transit/transshipped cargo and container by management of those facilities and lack of port efficiency and unable to produce good service to the port users. Mention that port governance acts as major engines for driving economics, in here, control of ports is a significant lever for government to manage the whole trade of the country to bring the economic benefits [17]. Therefore, port administration has to think positively to run the country, furthermore, explore a research regarding innovation for the maritime logistics industry to supply the port services to the shipper/consignee smoothly, timely and economically. In the research of $\mathrm{Wu}$ and Lin [18], for Indian Port Management, Bangladesh port facilities are feasible for NE (North-East) Part of India subject to the infrastructure and policy development of Bangladesh government.

\section{Maritime Logistics Business Opportunity}

There are huge opportunities in doing maritime logistics business regionally and internationally by providing port transport the neighbors and it is derived demand of those countries which are basically landlocked and facing the insufficient access to the seaport.

Integration among the foreland, seaports and hinterland will help to create shipping networks that are absolutely international for doing port transport business [19, 20]. Present shipping world is facing a volatile environment, dynamic markets and challenges by new environmental and social consideration, particularly, users are demanding innovative solutions to add value as well as resilience into the future maritime logistics industry exclusively in the operating seaports and its associated organizations [3]. In addition, Taneja et al. [3] added that globalization, achieving market place and rapidly changing technology are three major factors in the transition of port sectors that affected significantly. Emerging opportunities, Rahmatullah [21] anticipated that Bangladesh has unique geographical location with two landlocked countries Nepal and Bhutan. In addition, he explored that NE part or Seven Sister of India is basically landlocked and similar to Nepal and Bhutan. He dreamed to serve NE part of India by Chittagong Portand Nepal and Bhutan by Mongla Port. New construction of Padma Bridge will open the door for Nepal and Bhutan as well as for West Bengal of India as per opinion of the author that trusted from BBIN (Bangladesh, Bhutan, India and Nepal) networks of the region. In this context, Rahmatullah [21] calculated

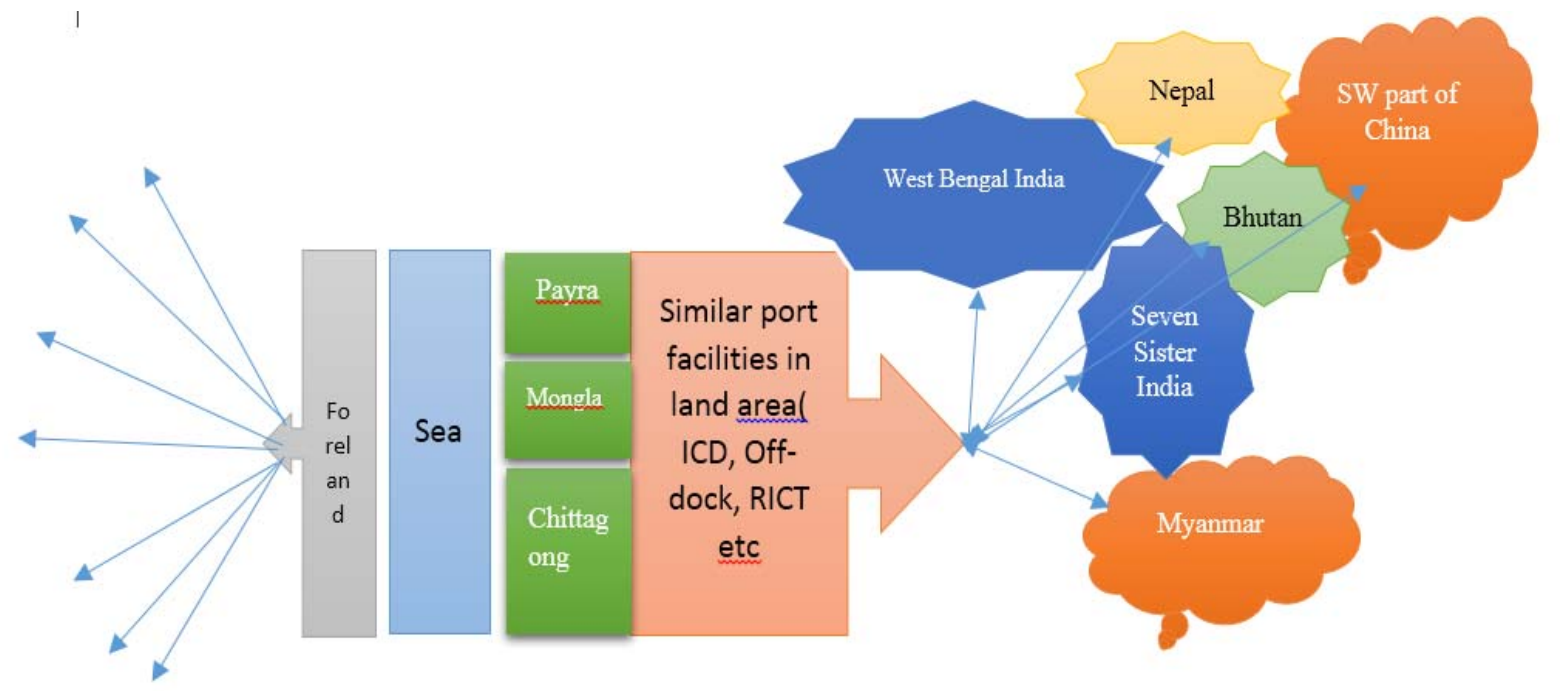

Fig. 2 (Diagram). Foreland and hinterland of Bangladeshi seaports developed by author. 
the cost of non-cooperation in transport is very high and throwaway and he argued to all to start "transport services" from Bangladesh to India, Nepal and Bhutan and it will be good for all. However, he explored that to establish regional transport connection, political commitment and stability is must for all countries that will bring the regional connection to trade with the out worlds and strengthen the regional connectivity.

The first condition of the maritime/port services is the quality and quality of the entire system from seaport to the final destination is totally depends on the good port management. Consequently, Zhang and Pel [22] requested for subsidy scheme from the government and port authority to promote intermodal freight transportation in the field of infrastructure, intermodal services and technologies. As this is the new concept, government and port authorities may take initiative and plan to work in the development of intermodal freight transport system as early as possible. In line with such motivation, Islam [23] stated that Chittagong port as regional port is historical and lone natural harbor of eastern sub region of South Asia with the prospects of aiding China for regional connectivity and international business respectively. He found the limitation of India to provide timely service from Kolkata or Haldia port where Chittagong and Mongla port is essential with the expression of Rahmatullah [21]. However, there is straightforward competition in the port business as stated by De Langen and Pallis [24], afterwards, it is necessary to take effective marketing approach in doing port transport business regionally and internationally.

\section{Research Methodology}

This research was started in December, 2014 and mind mapped in Hong Kong and brought the example of Port of Rotterdam to follow the case study of the research. However, this research has three fold research paths to follow the qualitative research methodology by following the guidelines of Neuman [25]. Notably, Galvao et al. [26] highlight about the business research specifically maritime/port business research and find specialized media reports, broadcastings, manuscripts and others national news which are able to identify the problems and issue well before the academic literature. Current media and online news are preliminary sources of collecting information to add in the academic literature. Mention that seaport academic literature had traditionally focused on improving port efficiency that resulted poor performance of seaport due to stakeholder conflict and fully absence of innovative process of port development. Unfortunately, there are limited literatures of innovation subjects regarding maritime industry before 2005 but Taneja et al. [3] describe the possible innovation of maritime industry from seaport to hinterland connections as well as intermodal freight transportation proudly.

Advanced technological circumstances, market imperatives and efficiency are being innovative in various economic sectors, therefore, applied research and developments in logistics and supply chain management is crucial greatly [2]. In here, logistics and shipping are remaining as a vital segment of trade including the process of integrating the movement of goods while shipping and logistics are likely to meet customer satisfaction rather than emphasizing on competitive advantage.

\section{Literature Review}

Literature review swallowed the related sentences of maritime logistics innovation in the current world especially in the developed countries of the world. Historically, seaport sectors are the source or center point of maritime logistics to produce port transport, therefore, innovation in the seaport is the prime activity to develop the industry in a profitable way [27]. This literature review explores the innovations of seaport firstly, after that logistics and supply chain for domestic's requirements that turned to regionalization and international business focuses at the last paragraph as concluded review. Innovations are the way of 
attracting port users to connect and select the gateway to do import export business and others with the current world traders. It is often suggested that new service marketing and new product orientation are the special innovations of port authority to get more customers within the country or attract others for earning foreign exchange incredibly. Muntean et al. [28] argued for high levels of port and transport development exclusively for developing countries of the world as they are at slow in exports and lack of diversification in port management, moreover, dependency on commodity prices on international markets. In addition, Notteboom and Rodrigue [8] articulated the global changes in production and consumption where regional production and consumption system permits the development of a distribution network, finally, regionalization of ports. Meanwhile, Taneja et al. [3] describe the degrees of innovation of port that will help to assess the port authority to develop the strategy to sustain in the competition or business rivalry with other ports.

The above literature recommends the below innovations for Bangladeshi seaports as stated by the author:

International supply chains are complex and logistics models that are evolved continuously because of influences and factors such as the globalization and expansion into new markets, lean manufacturing practices that related to shifting of costs [29]. To response against the complexity and mounting the challenges, maritime and logistics industry had seen a massive consolidation and vertical integration also regional diversification of port development to inspire the trader to take the reasonable access/facilities of port transport. The competitiveness of regional ports (with the seaports of India and Myanmar) into global supply

Table 1 Degrees of innovations in ports [3].

\begin{tabular}{|c|c|c|c|}
\hline Types & Incremental adaptation & Evolutionary Innovation & Revolutionary Innovation \\
\hline Definition & $\begin{array}{l}\text { It is called adaptive or efficiency } \\
\text { innovation that is focusing the } \\
\text { exiting port facilities. It offers to } \\
\text { reduce cost per service, improves } \\
\text { product and enhances the quality } \\
\text { of the port services etc. }\end{array}$ & $\begin{array}{l}\text { It addresses existing or new issues } \\
\text { with the state of the art approaches or } \\
\text { techniques to target the new markets. } \\
\text { It refers to distinctly better products } \\
\text { and processes near to incremental } \\
\text { innovation. }\end{array}$ & $\begin{array}{l}\text { It focuses on radically new and } \\
\text { better ideas to transform or even } \\
\text { dismantle the existing structure, } \\
\text { technology or processes of the port } \\
\text { or related organizations, lead to the } \\
\text { discovery of new things } \\
\text { innovatively. }\end{array}$ \\
\hline Prime Mover & Market Forces & Market Forces & $\begin{array}{l}\text { Derived demand of the port users, } \\
\text { customer demands. } \\
\text { Regionalization and Globalization }\end{array}$ \\
\hline Costs/Resources & $\begin{array}{l}\text { Small. Local Finance or } \\
\text { Public-Private Partnership } \\
\text { Initiative is appreciated } \\
\end{array}$ & $\begin{array}{l}\text { Large. Port terminal operator's } \\
\text { Alliance or Foreign Direct } \\
\text { Investment is appreciated } \\
\end{array}$ & $\begin{array}{l}\text { Very Large. Huge investment is } \\
\text { required. }\end{array}$ \\
\hline Issues/Opportunities & Existing or predictable & Both Existing and new & New \\
\hline Associated uncertainty & Small & Small to large or medium & Cannot be assessed \\
\hline \begin{tabular}{|l|} 
Routines/ \\
Procedures
\end{tabular} & \begin{tabular}{|l|} 
Routines or a \\
variations/combinations
\end{tabular} & $\begin{array}{l}\text { Changing trajectories, flexible uses of } \\
\text { routines }\end{array}$ & Routines mostly violated \\
\hline Markets & Targeted at existing markets & Targeted at existing and new markets & Disrupts existing markets \\
\hline Overall & $\begin{array}{l}\text { To address the current problems } \\
\text { and may prove limiting through } \\
\text { shifting focus. }\end{array}$ & $\begin{array}{l}\text { Directs at anticipating new problems } \\
\text { and long term thinking about future } \\
\text { developments. }\end{array}$ & $\begin{array}{l}\text { Activates by inadequate solutions } \\
\text { of existing problems to address the } \\
\text { large scale demand in regional or } \\
\text { global perspective }\end{array}$ \\
\hline
\end{tabular}

Table 2 Innovations for Bangladeshi seaports tabulated by the author.

\begin{tabular}{|l|l|l|l|}
\hline Types & Incremental adaptation & Evolutionary Innovation & Revolutionary Innovation \\
\hline Port & Mongla & Chittagong and Payra & Chittagong \\
\hline Justification & $\begin{array}{l}\text { It is the planned innovation to } \\
\text { follow the existing facilities of } \\
\text { Chittagong port and develop } \\
\text { accordingly }\end{array}$ & $\begin{array}{l}\text { It is also planned innovation that } \\
\text { recommended for Chittagong and } \\
\text { Payra port to offer new business } \\
\text { products within the existing facilities }\end{array}$ & $\begin{array}{l}\text { This is the unplanned innovation that } \\
\text { recommended for Chittagong for thinking } \\
\text { to serve the whole country and neighbors } \\
\text { also expertise to handle other port by } \\
\text { financing own fund }\end{array}$ \\
\hline
\end{tabular}


chains and shipping networks demanded an adequate responses to cope with the changes of traffic patterns, freight diversity and routes to attract the shipping companies, shippers, consignees, international and local traders as well as port users inevitably. Furthermore, Notteboom and Rodrigue [8] explored that inland distribution is the very important dimension of the globalization, maritime transportation as well as freight distribution paradigm where customers are calculating the total logistics costs of containerized goods that are derived for a large part from inland distribution. They emphasized on the inland freight distribution that helped to do port regionalization and as an indicator of port competitiveness.

In a study, Ghosh and De [30] argued that a rising hinterland/foreland helps the port to sustain its growth degree of its involvement with global trade and it is necessary to strengthen the port system to mitigate the extra port service demand of other countries as well as to sustain with the rising overseas trade. In here, government should apply or create the full pledged policy initiative for future investment in port development where Saha [20] accentuated that port development is essential for Bangladesh to serve nationally and have the opportunity to sell port services regionally and internationally. However, seaports position in the international transport chain and its importance of world trade are incredible and seaports are playing a vital role in the regional economic development and affecting the regions viability, prospectus and propensity for growth of own country also regional development [31].

Amounting the freight that are increasing container throughput in the ports also leads to increasing transport volumes in their hinterlands and this has also brought the issue of capacity and quality of the hinterland transport system to thefore. Visser et al. [32] argued that development of intermodal hinterland transport (rail and barge), enabling large-scale transport services, is gaining importance to keep the port accessible by shifting cargo way from the congested roads to the railways and waterways. Furthermore existing transport modes will always play a role in the movement of containers to and from the ports. Current congestion problems in ports and on the infrastructure near ports force us to look at new port concepts. New port concepts in which the "port entry" is shifted to an inland location, accompanied by a movement of all kinds of operations, as buffering, stripping and stuffing and warehousing, contribute to solving the port problems, such as congestion and lack of space. Despite an extensive literature on innovation especially in maritime logistics industry, it is rare to find related contents. Although the title of the research is searching the innovations that will help to generate new idea or business strategy to cope with the derived demand of port transport for developing international business in the region greatly.

\section{Case Study: Port of Rotterdam}

This research added the case study of Port of Rotterdam and found the strategy and marketing policy to attract the shipper, consignee, main line operators, terminal operations and others, overall, port users to use the port as trusted partner of maritime logistics in the trade world. The Port of Rotterdam is the Europe's largest seaport which owes its leading position to its excellent accessibility for seagoing vessel and intermodal freight transport connection, moreover, a place of unlimited ambitions can become reality [33]. Port of Rotterdam features an extensive intermodal freight transportation network of rail, road, inland shipping, short sea and pipelines that connected with the rest part of the Europe by depending on the volume, desired speed, expenses and sustainability goals with fully combination of various modes. Remarkably, all freight reached from the perfect located intermodal terminals to the destination within 24 hours and real time combination of rail, road, short sea and inland shipping. In this context, the author found the similar opportunities for intermodal connection from Bangladeshi seaports to provide maritime logistics 


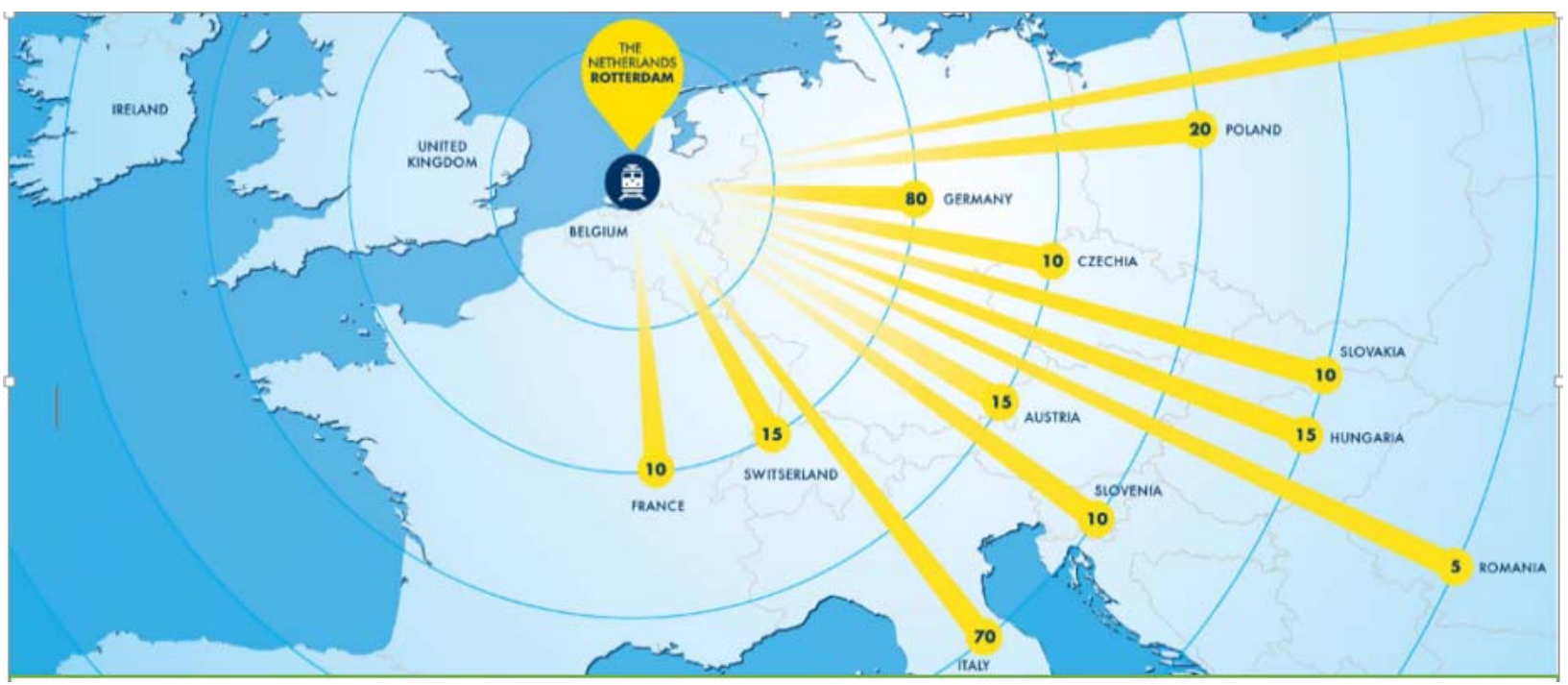

Fig. 3 (Map). Hinterland connections of port of Rotterdam [33].

Table 3 Innovations for port of Rotterdam [3].

\begin{tabular}{|c|c|c|c|c|c|}
\hline $\begin{array}{l}\text { Innovative } \\
\text { Concept }\end{array}$ & Issues/advantages & \begin{tabular}{|l|} 
Procedures/ \\
processes
\end{tabular} & $\begin{array}{l}\text { Market } \\
\text { uncertainty }\end{array}$ & $\begin{array}{l}\text { Contributions to } \\
\text { Sustainability } \\
\end{array}$ & Remarks \\
\hline \begin{tabular}{|l|} 
MultiCore \\
Pipeline \\
(Specialized \\
pipeline for oil, \\
chemical, gas and \\
others) \\
\end{tabular} & \begin{tabular}{|l|} 
It is efficient to use port \\
spaces and improve the \\
accessibility to port. In \\
addition, it is environment \\
friendly and reduced the \\
emission of $\mathrm{CO}_{2}$.
\end{tabular} & $\begin{array}{l}\text { Innovative design of pipe } \\
\text { bundle and interaction with } \\
\text { legal bodies for permits. } \\
\text { Subsidy grants from the } \\
\text { government for } \\
\text { establishing the line. }\end{array}$ & Medium & $\begin{array}{l}\text { High as underground } \\
\text { infrastructure is } \\
\text { required }\end{array}$ & $\begin{array}{l}\text { Need to facilitate in } \\
\text { all Bangladeshi ports } \\
\text { and may offer to } \\
\text { India, Nepal and } \\
\text { Bhutan }\end{array}$ \\
\hline $\begin{array}{l}\text { CT (Container } \\
\text { Transferium) } \\
\text { Single transfer to } \\
\text { inland vessels }\end{array}$ & $\begin{array}{l}\text { It is efficient to use the } \\
\text { spaces of terminals and } \\
\text { equipment's as well as } \\
\text { improves the accessibility } \\
\text { to port. In addition, it is } \\
\text { environment friendly and } \\
\text { reduced the emission of } \\
\mathrm{CO}_{2} \text {. It reduces the } \\
\text { multiple handling of } \\
\text { container at port. }\end{array}$ & $\begin{array}{l}\text { New business model and } \\
\text { interaction with the market } \\
\text { also with the legal bodies } \\
\text { for permits. } \\
\text { Subsidy grants from the } \\
\text { port authority for } \\
\text { purchasing the equipment. }\end{array}$ & Low Medium & $\begin{array}{l}\text { High that promotes } \\
\text { the modal shifting in } \\
\text { the intermodal } \\
\text { freight } \\
\text { transportation } \\
\text { system nicely and } \\
\text { reduced the handling } \\
\text { time at port premises }\end{array}$ & $\begin{array}{l}\text { Need to orient and } \\
\text { install in all } \\
\text { Bangladeshi } \\
\text { seaports for } \\
\text { transferring } \\
\text { containers from } \\
\text { seaport to inland } \\
\text { vessels for sending } \\
\text { to RICT. }\end{array}$ \\
\hline $\begin{array}{l}\text { Combi-road } \\
\text { (Moving } \\
\text { container in the } \\
\text { special track of } \\
\text { High way) }\end{array}$ & $\begin{array}{l}\text { It improves the } \\
\text { accessibility and reduced } \\
\text { the congestion at port } \\
\text { protected area and at } \\
\text { highway }\end{array}$ & $\begin{array}{l}\text { Intensive Research and } \\
\text { development }(R \& D) \text { is } \\
\text { appreciated where } \\
\text { investment is required for } \\
\text { separate lane in the } \\
\text { highways } \\
\end{array}$ & \begin{tabular}{|l|} 
Low where \\
users will save \\
time in the \\
process of \\
import and \\
export \\
\end{tabular} & Medium & $\begin{array}{l}\text { Need to study } \\
\text { preliminary for } \\
\text { Dhaka-Chittagong } \\
\text { Highway and in the } \\
\text { Chittagong Port }\end{array}$ \\
\hline $\begin{array}{l}\text { Floating Crane } \\
\text { (Specialized crane } \\
\text { at river side or at } \\
\text { sea) }\end{array}$ & $\begin{array}{l}\text { It reduced the congestion at } \\
\text { port protected area. } \\
\text { Direct transfer of cargo and } \\
\text { container without laying at } \\
\text { port }\end{array}$ & R\&D & High & $\begin{array}{l}\text { High that promotes } \\
\text { the modal shifting }\end{array}$ & $\begin{array}{l}\text { Need to apply in all } \\
\text { Bangladeshi port for } \\
\text { intermodal from } \\
\text { seaport to RICT }\end{array}$ \\
\hline
\end{tabular}

support as well as to do port transport business regionally with India, Nepal and Bhutan and internationally with China and Myanmar.

To describe the rail transport, it is fast, efficient, reliable and sustainable and port authority denoted the rail transport as ideal for transporting the cargo across long distances and transporting long volumes efficiently and rapidly. In addition, inland shipping is a reliable, low costs, safe and environment friendly way of transporting cargo from port and vice versa. Finally, the fast option is the road transport by trucking or trailers to and from the port and will reach to the front 
door, regardless of location or time.

To apply in the port of Rotterdam Taneja et al. [3] brought some innovation concepts like multicore pipeline, container transferim, multi-functional quay, multi-user terminal, combi-road and floating crane where first two are functional and others are on the shelf. However, this study featured four for applying in the Bangladeshi seaports as stated bellows.

Overall, this case study inspired the Bangladeshi seaports to apply the innovations and technology of Rotterdam port as both have same hinterland opportunity where Port of Rotterdam is successful.

\section{Qualitative Research Findings}

By visiting the port of Hong Kong, Chittagong and Mongla and studying the related literature from the secondary sources, direct interviews were conducted where 10 respondents delivered their qualified opinions and assisted to find out the innovations of maritime logistics regarding Bangladesh. Important dialogues were extracted from the interviews and summarized as bellow.

\subsection{The Features of Bangladeshi Seaport}

Most of the respondents are remarked that Bangladeshi seaports are potential in front of the world trader and worlds that are looking forward to seeing all of those ports as international maritime load center and the access of the region to enter in the global trade. They recommended that Bangladesh should highlight the main features of seaports to the business world and offer business in Bangladesh and hinterland of seaports possibly.

\subsection{Key Factors and Competitive Advantages}

All respondents replied that geographical position and geopolitical advantages are the key factors of Bangladeshi seaports to attract the world trader to do business in Bangladesh. Low payment of qualified and skilled labors are inspired to improve the quality of readymade garments where easy seaport access and quick shipment of cargo and container helped to set world standard factories in Bangladesh that enabled the competitive advantages in all kinds of product "Made in Bangladesh". In addition, position of Chittagong Port is really lucrative not only for Bangladesh but also for Nepal, Bhutan and West and NE part of India.

\subsection{Role of Chittagong Port}

All respondents appreciated the role of Chittagong Port Authority in serving the nation silently and playing a vital role in national development. Recent activities of Chittagong port in establishing Pangaon RICT and Payra seaport are escalating the national economy and will help the neighbors nicely.

\subsection{Intermodal Freight Transportation}

There is no alternative to design the intermodal freight transportation system and adopt the policy by following the developed countries system. Most of the respondents referred the name of Hong Kong, Rotterdam, Singapore to work with them as collaboration for development. One scholar advised to do research on intermodalism and draft the operating procedures to implement the intermodalism as early as possible.

\subsection{Obstacles in the Process of Port Development}

Most of the respondents worried about the cancellation of Sonadia Deep seaport project and guessed some conspiracy here internationally where someone stated that this is the advantages of neighbor countries where efficiency of Chittagong port is ignored completely. Government is not trying to do port transport business by utilizing the national resource.

\subsection{Innovation or Innovative Idea}

During the qualitative interview, research found the below innovation idea that is remarkable for Bangladesh Maritime Logistics Industry as bellows:

(a) Construct separate highway in Dhaka-Chittagong 
for cargo and container.

(b) Install the rail track separately from Chittagong port to Dhaka.

(c) Strengthening cargo handling system and purchase latest equipment in all seaports.

(d) Integration among the seaports in Bangladesh

(e) Deploy skilled staff to Mongla and Payra Port to exchange the experience

(f) Appoint qualified international terminal operator in RICT Pangaon.

\subsection{Any Suggestions}

Maximum respondents counseled that Bangladesh Government should open the seaports for neighbors but must pay reasonable charge to the user. Openness to the neighbor is important and Bangladesh must play a role in their development especially for Nepal and Bhutan. Bangladesh may appeal to India or connect through BBIN (Bangladesh-Bhutan-India-Nepal) network to get the road from Northern part of Bangladesh to Nepal /Bhutan/China also provide access to West Bengal and NE part (Seven Sister) of India. Regarding innovation, respondents are keen to know more about the initiative of the government and raise the concern of moving containers here and there without any intermodal policy where roads are unable to tolerate the load of cargo and container.

\section{Compare and Contrast}

There are some variations in between the literature and qualitative research findings but in maximum cases research found the similarities and stated the below innovations that will help Bangladesh to develop their port transport facilities, transport policy and level playing environment to solve the problems in serving domestics services and keep ready for foreign business profitably. In order to secure the maritime logistics trade, port qualities have a stake with the innovations for improving operations, gaining competitive advantages, achieving and maintaining a "license to operate" and finally achieving resilience against a changing environment [3]. Furthermore, ports connection with the hinterland organization is also important because of their connections with the ports timely and in the process of innovation to achieve the common goal of logistics and serve the port users seamlessly. In addition, dry port presence in Asia is an average position comparing with the developed world [5]. Mention that dry ports in Bangladesh are at an early stage of development. In this connection, Hanaoka and Regmi [5] elucidate the potential environment benefits of intermodal integration through the developments of dry ports enthusiastically.

Furthermore, Galvao et al. [26] explored that port modernization process takes place in context of globalization to increase volume and to accommodate the diversity of global trade. Moreover, PPP and role of port stakeholder also plays a role in the seaport development and create the good connections with the hinterland. In additions of Dash's [19] regional institutional structures, Montwill [34] structured the seaport functions from the nearby industry and up to regional functions as spatial functions to provide services regionally where urban functions are important because people and industry both favored to stay over there for earning, education and physical treatment opportunity. In this research, innovations from the literature review, respondent's opinion and case study guided to apply the innovations in the Bangladeshi seaports for developing maritime logistics industry as derived demand of the nation and region.

\section{Conclusions}

This research found some innovation in maritime logistics from the literature review and direct interview with the respondents in qualitative research finding where respondents had quoted the innovations from their experience in the sector and thoughts to set the standard seaport facilities in Bangladesh that will attract the international traders for investing in Bangladesh undoubtedly. And then, it is a unique way to promote export business and by offering seaport 
access through intermodal freight transport, opening the door of earning foreign exchange as well as employing the people.

To sum up, the phase of the regionalization brings the perspective of port development to a higher geographical scale to provide service in a big scale of port transport services [6]. It's a part of initiative to grow regional port and stay with the rivalry ports of neighbors. Just then, Notteboom and Rodrigue [8] advised to port authorities for promoting an efficient intermodal freight transportation system for securing the cargo under high competition of maritime logistics markets.

Finally, port authorities can play an important role in the process of inland distribution by applying the innovation stated in this research (intermodality, dry port concept, using information technology as well as automation) for gaining competitive advantages with other regional seaports. Lastly, with the voice of Jacobs and Notteboom [29], to be successful, port authorities have to think along with the customers and figure the needs, driven in particular, not only in the port but throughout the supply chain and networks. In the light of predicted growth of freight transport, two possible ways are to enhance the quality of conventional modes of transport and develop alternative transport systems. To enhance the quality of existing set up of port transport and find out the alternative transport, this paper was planned to get some innovative idea and found greatly from the literature of innovation regarding seaport, maritime logistics and port transports especially some innovations of Rotterdam port that will help to develop maritime logistics industry of Bangladesh in future.

\section{Future Directions}

Research bought some future directions to the reader, policy makers and others by which Bangladesh may develop their maritime logistics transport industry in the light of innovations for maritime logistics industry.

- The World Bank published the Port Reform
Toolkit in 2001 and updated in 2007 and aimed to provide support public sector for working with the private sector in the aim of infrastructure development of seaport and its connectors with the shipper/consignee premised by developing the infrastructure of road, rail and waterways. Need to work as per guideline of Port Reform Toolkit and open the door for both public and private investors.

- Implementation of green transport policy at everywhere and protect the environment of seaports, terminals and reduce the emissions from the transport vehicle exclusive reduce the emissions from trucks and trailers.

- Design, operations and policy of intermodal freight transport by the government with the financial helps from international donor submit proposal for intermodal infrastructure development.

- Dry port concept and convert or shape the dry port facilities in all land port of Bangladesh by putting import-export facilities through container by using the access of Bangladeshi seaports.

- Arrangements of Transit, Transshipment in the spatial or river and coastal shipping for the neighbors to do port transport business.

- Taneja et al. [3] advised that investigation the barriers to innovation in the port sector is essential and need to identify before taking the initiative of implementation in specific works rightly. In this connection, Bangladeshi seaports may take initiative to investigate own position and add innovation as per requirements of port users.

- Infrastructural development revealed the consideration for operational issues of maritime logistics industry. Therefore, it is essential to take initiative for infrastructure development of port and intermodal links.

- Need to think about PICT and may lease to the leading container operators in Bangladesh to offer the services in PCT instead of Chittagong Port. It's a common practice in the developed country to operate the terminal by main line operator like Maersk 
Line/OOCL/others.

- Montwill [34] analyzed that port development strategy is based on the use of advanced automation and information technology. Automation is recommended for quick documentation and custom clearance timely and swiftly.

- Port infrastructure is not limited to inside the port only, hinterland oriented infrastructure is also important to assess the critical success factors of seaport in the perspective of Public-Private Partnership [35]. Need to exercise Public-Private Partnership-PPP in the port, terminal and intermodal infrastructure development.

\section{Acknowledgement}

This research is acknowledging the sincere cooperation of my wife POMPA SAHA who inspired to write about innovations of Bangladesh maritime logistics industry and helped to collect data and conduct qualitative research interviews from December 2014 to December 2016.

\section{References}

[1] Graham, G. 2008. "Understand Innovation in 5 Minutes." Accessed November 2016. http://www.slideshare.net/Brokenbulbs/understand-innov ation-in-5-minutes?qid=0ebc0045-fb4a-4207-8615-d1c12 $1717 \mathrm{f0e} \& \mathrm{v}=\& \mathrm{~b}=\&$ from_search $=3$.

[2] Allate, B. M. 2015. "Shipping Management and Logistics Innovation: Key Factors for Success." International Journal of Management Science and Business Administration 2 (1): 50-5.

[3] Taneja, P., Vellinga, T., and Schuylenburg, M. V. 2012. "Ports and Innovation. Proceedings of the World." Presented in the Conference on Transport Research Society, WCTRS, SIG-2 Special Interest Groups 2, Maritime Transport and Ports, Antwerp, Belgium, June 21-2.

[4] Hanssen, T-E. S., Mathisen, T. A., and Jørgensen, F. 2012. "Generalized Transport Costs in Intermodal Freight Transport." Procedia-Social and Behavioral Sciences 54: 189-200.

[5] Hanaoka, S., and Regmi, M. B. 2011. "Promoting Intermodal Freight Transport through the Development of Dry Ports in Asia: An Environmental Perspective." IATSS Research 35:16-23.
[6] Rodrigue, J-P., and Notteboom, T. E. 2010. "Foreland-Based Regionalization: Integrating Intermediate Hubs with Port Hinterlands." Research in Transportation Economics 27 (1): 19-29.

[7] Acciaro, M., Vanelslander, T., Sys, C., Ferrari, C., Roumboutsos, A., Giuliano, G., Lam, J. S. L., and Kapros, S. 2014. "Environmental Sustainability in Seaports: A Framework for Successful Innovation.” Maritime Policy and Management 41 (5): 480-500.

[8] Notteboom, T. E., and Rodrigue, J-P. 2005. "Port Regionalization: Towards a New Phase in Port Development." Maritime Policy and Management 32 (3): 297-313.

[9] CPA. 2016a. "Introduction: Chittagong Port Authority." Accessed December 10, 2016. http://Cpa.Gov.Bd/Introduction-Chittagong-Port-Authorit $\mathrm{y} /$.

[10] CPA. 2016b. "Containers Handling Statistics of Chittagong Port." Accessed December 10, 2016.http://Cpa.Gov.Bd/Containers-Handling-Statistics-C tg-Port/.

[11] HPC. 2015. “Asian Development Bank's Technical Assistance Consultant's Report for People's Republic of Bangladesh: Strategic Master Plan for Chittagong Port.” Final Report, Part 3, HPC-Hamburg Port Consulting GmbH, Hamburg, Germany.

[12] Mongla Port. 2016. "The Future Prospect and Potentials of Mongla Port Especially after Completion of the Padma Bridge." Accessed December 12, 2016. http://www.mpa.gov.bd/bn/benefit.

[13] Payra. 2016. "Welcome to Payra Port Authority." Accessed December 12, 2016. http://ppa.gov.bd/welcomepost/welcome-to-payra-port-au thority/.

[14] PICT. 2016. “About.” Accessed December 12, 2016. http://pict.gov.bd/about.

[15] Sarwaruddin. 2015. "Privatization of Pangaon Container Terminal Finalized." Accessed June 12, 2015. http://businessnews24bd.com/privatisation-of-pangaon-co ntainer-terminal-finalized/.

[16] Chittagong Custom House. 2016. "Listed Off-dock at Chittagong Custom House.” Accessed December 08, 2016. http://chc.gov.bd/imp/offdock.php.

[17] Monios, J., and Bergqvist, R. 2015. "Intermodal Terminal Concessions Lessons from the Port Sector." Research in Transportation Business and Management 14 (1): 90-6.

[18] Wu, Y. J., and Lin, C. 2008. "National Port Competitiveness: Implications for India." Management Decision 46 (10): 1482-507.

[19] Dash, K. C. 2008. Regionalism in South Asia: Negotiating Cooperation, Institutional Structures. New York: Routledge. 
[20] Saha, R. C. 2015. "Port Development in Bangladesh." European Journal of Business and Management 7 (7): 392-9.

[21] Rahmatullah, M. 2010. "Regional Connectivity: Indo-Bangla Initiative." The Daily Star, February 24 2010.

[22] Zhang, M., and Pel, A. J. 2016. "Synchromodal Hinterland Freight Transport: Model Study for the Port of Rotterdam." Journal of Transport Geography 52: 1-10.

[23] Islam, M. 2016. "Regional Connectivity: Current Challenges for Bangladesh." Presented in the Seminar of Bangladesh Economic Society-Chittagong Chapter, March 19, 2016.

[24] De Langen, P. W., and Pallis, A. A. 2006. "Analysis of the Benefits of Intra-port Competition." International Journal of Transport Economics 33 (1): 69-85.

[25] Neuman, W. L. 2011. Social Research Methods: Qualitative and Quantitative Approaches. Essex, England: Pearson Education Limited.

[26] Galvao, C. B., Wang, G. W. Y., and Mileski, J. 2016. "Public-Private Interests and Conflicts in Ports: A Content Analysis Approach." The Asian Journal of Shipping and Logistics 32 (1): 13-22.

[27] Carbone, V., and De Martino, M. 2003. "The Changing Role of Ports in Supply-Chain Management: An Empirical Analysis." Maritime Policy and Management 30 (4): 305-20.

[28] Muntean, M. C., Nechita, D., Nistor, C., and Şarpe, D. 2010. "Port Management Importance in Port Activities Development." In Proceedings Paper of the 3rd WSEAS International Conference on Urban Planning and
Transportation (UPT '10), 180-6.

[29] Jacobs, W., and Notteboom, T. 2009. "A Theory on the Co-evolution of Seaports with Application to Container Terminal Development in the Rhine-Scheldt Delta." In Proceedings of the 2009 International Association of Maritime Economists (IAME) Conference, June 2009, Copenhagen, Denmark.

[30] Ghosh, B., and De, P. 2001. "Indian Ports and Globalization: Grounding Economics in Geography." Economic and Political Weekly 36 (34): 3271-83.

[31] Munisamy, S., and Singh, G. 2011. "Benchmarking the Efficiency of Asian Container Ports." African Journal of Business Management 5 (4): 1397-407.

[32] Visser, J., Konings, R., Pielage, B., and Wiegmans, B. 2000. "A New Hinterland Transport Concept for the Port Of Rotterdam: Organizational and/or Technological Challenges?" Transport Research Forum, March 15-17, 2007, Boston, Massachusetts.

[33] Port of Rotterdam. 2016. "Liner Services." Accessed November $12,2016$. https://www.portofrotterdam.com/en/connections-logistic s/liner-services.

[34] Montwill, A. 2014. "The Role of Seaports as Logistics Centers in the Modeling of the Sustainable System for Distribution of Goods in Urban Areas." Procedia-Social and Behavioral Sciences 151: 257-65.

[35] Aerts, G., Grace, T., Dooms, M., and Hazendonck, E. 2014. "Public-Private Partnership for the Provision of Port Infrastructure: An Explosive Multi-Actor Perspective on Critical Success Factor." The Asian Journal of Shipping and Logistics 30 (3): 273-98. 


\section{Appendix A. Research Questionnaire}

From the experience of visiting local and international seaport from December 2014 to June 2016, this research developed one questionnaire and worked with the responded as follows:

1.What are the features of Bangladeshi seaports to serve the neighbors regionally and internationally?

2.What are the key factors and competitive advantages of Bangladeshi Seaports with other regional ports?

3.How Chittagong Port of Bangladesh will help to create the environment for doing port transport business and develop other Seaports of Bangladesh?

4.Do you think that Intermodal Freight Transportation is the best way to offer port transport service to the neighbors?

5.What are the obstacles in developing integrated maritime logistics networks in the region by centering Chittagong Port as Regional Maritime Load Center?

6.Do you have any innovative idea or refer any innovation that will help to faster maritime logistics industry of Bangladesh for doing maritime port transport business?

7.Any suggestion from your end to develop our port transport and seaport.

\section{Appendix B. List of the participants in the qualitative survey}

\begin{tabular}{lllll}
\hline SL No & Code & Designation and others & Country & Remarks \\
\hline 01 & A & Policy Researcher & Bangladesh & Direct Interview \\
02 & B & Ph.D. Researcher in Transport Management & Bangladesh & Direct Interview \\
03 & C & University Teacher & Hong Kong & Direct Interview \\
04 & D & Owner of Shipping Company-Local & Bangladesh & Direct Interview \\
05 & E & Port Transporter & Bangladesh & Telephonic Interview \\
06 & F & Maritime Journalist & UK & Telephonic Interview \\
07 & G & Ex-port Manager (Training) & Bangladesh & Direct Interview \\
08 & H & Port User and Stakeholder & Bangladesh & Direct Interview \\
09 & I & Seafarer and Port Consultant & Bangladesh & Telephonic Interview \\
10 & J & Economist & Bangladesh & Telephonic Interview \\
\hline
\end{tabular}

Acknowledgement. I am greatly indebted to my wife Pompa SAHA who inspired to write this paper and research on innovation in maritime industry of Bangladesh and my UK friend Md. Foyzul Hoque SUJON for financing this research momentously.

Special Note. This research is a part of $\mathrm{PhD}$ research for awarding $\mathrm{PhD}$ in Center for Higher Studies and Research, Bangladesh University of Professionals (BUP),Mirpur Cantonment, Dhaka1216, Bangladesh. In this connection, I am grateful to our honorable Dean Brigadier General Syed Mofazzel MOWLA (Retd.) of BUP for his kind guidance and motivation. 